\title{
Theory of Social Representations and the Aging: a Bibliometric Profile
}

Karoline Lima Alves ${ }^{1}$, Antonia Oliveira Silva², Ana Karênina de Freitas Jordão do Amaral², Samilla Gonçalves de Moura ${ }^{4}$, Carla Braz Evangelista5 ${ }^{5}$, Célia Maria Cartaxo Pires de Sá6, Silvia Brenna7, Maria do Céu Mendes Pinto Marques ${ }^{8}$, José Luiz Telles de Almeida ${ }^{9}$, Maria Virgínia Tavares Cruz Vitoriano ${ }^{10}$, Maria Adelaide Silva Paredes Moreira ${ }^{11}$

\section{Abstract}

Introduction: The aging is a process that can be either positive or negative. When a theme refers to positions or attitudes, social representations may comprehend and explain these phenomena.

Objective: With the help of the bibliometrics research, the study focused on describing the scientific publications about social representations of aging, and investigating them.

Method: Analysis of the available content in the online databases of the Virtual Library in Health, PubMed and Portal Capes, from 2010 to 2015. The keywords social representations and aging were used. By simple descriptive method, frequency and percentage, the following variables were described: authors; authors' education; maximum qualification of the authors; index $\mathrm{H}$; authors' institution; journal; year of publication; journal's impact factor; research's place; research's development; research's objective; the most relevant results; and keywords. For graphical representation of conceptual maps of keywords the software CMap Tools version 5.03 was used and for the analysis of the objectives and the most relevant results the thematic content analysis technique was used.

Results: A total of 127 scientific articles were found; after excluding those that were not in accordance with the chosen criteria, 42 files were found. One notices, regarding the authorship of the articles, a decentralization, with more authors from Northeast. The exploratory study and the mixed approach represented the most used research's method. The publications increased in 2011.
1 MSc. Federal University of Paraíba, João Pessoa, Paraíba, Brazil.

2 Nurse. PhD. Federal University of Paraíba, João Pessoa, Paraíba, Brazil

3 Speech Therapy. PhD Student. Department of Speech Therapy, UFPB. João Pessoa, Paraiba, Brazil.

4 Nurse. PhD Student. Federal University of Paraíba. João Pessoa, Paraíba, Brazil.

5 Nurse. MSc. University Center of João Pessoa, João Pessoa, Paraíba. Brazil.

6 Nutritionist. MSc. Federal University of Paraíba, João Pessoa, Paraíba, Brazil.

7 Nurse. Federal University of Paraíba. João Pessoa, Paraíba, Brazil.

8 Nurse. Teacher/coordinator. University of Evora. Portugal.

9 Doctor. Oswaldo Cruz Foundation-Rio de Janeiro, Brazil. Visiting professor of New University of Lisbon-Lisboa, Portugal.

10 MSc. Teacher, classroom support pole coordinator of the Open University of Brazil and Technological Vocational Center. Ceará, Brazil.

11 Physioterapist. PhD. Department of Speech Therapy, UFPB. João Pessoa, Paraiba, Brazil.

\section{Contact information:}

Karoline de Lima Alves.

झ krol_lima_17@hotmail.com 
Conclusion: The publications denote that the dependence on another person in performing daily activities interferes with the quality of life; they pointed out the social representations and positioning about the theme, important in identifying the weaknesses and vulnerabilities experienced by the elderly.

\section{Keywords}

Health Research; Aging; Social Representations; Bibliometrics; Journal.

\section{Introduction}

The aging is increasing significantly regarding other age groups. As it is a natural process, this phenomenon denotes projections to the next generations, caused by the improvement of the conditions of the people's life.

In Brazil, in 2013, data from the Brazilian Institute of Geography and Statistics (IBGE) show that, in 2050, there will be 1,900 million elderly people, a number parallel to the children's population from 0 to 14 years old. Nowadays, the elderlies represent $8.6 \%$ of the Brazilian population, which means almost 15 million people with 60 years or more. In 2025 , the percentage will be $15 \%$, that is, Brazil will have 32 million elderlies. [1]

Aging is a dynamic, individual and progressive process, seen in different forms by different cultures. Positively or negatively, when a theme refers to positions or attitudes, social representations may, regarding the social, economic and demographic context, comprehend and explain these phenomena. [2]

In this regard, the Theory of Social Representations is known as a form to comprehend the individual and collective conducts, practices and behaviors, characterized by the interactions of social groups about their daily issues. These questions are called common census theories, and occur in two processes: objectification and anchoring. [3]

The objectification can be seen as the representation of the path of social elements until they acquire materiality. The anchoring is defined as the representations of already constituted objects. [4]
By understanding the social knowledge about ageing is determined by beliefs, myths, prejudices, among others, often by the elderly themselves, in which every individual, according to your standards set the aging process for often stigmatized.

As an example, there was a study conducted in the city of João Pessoa/PB, in 2011, with 250 elderlies from the Family Health Units, in which the perception of "being old" was more favorable. When asked, the elderlies pointed out their condition of being old as an important aspect to their own health. [5]

With the help of the bibliometrics, known as a science with statistical and mathematical techniques to improve the areas of literature and other databases6, this study's objective was to describe and investigate the scientific publications about social representations and aging.

\section{Method}

This study used the bibliometrics research for enabling a quantitative analysis of the productions and publications about certain theme. [6] It was developed with the analysis of the available articles in the online databases of Virtual Library in Health (BVS), PubMed and Portal Capes, from 2010 to 2015.

The keywords social representations and aging were used to locate the articles; the following inclusion criteria were used: published as a scientific article (original or revision); fully available; published from 2010 to 2015; and presenting contextualization about social representations and aging. 
The following exclusion criteria were used: the publications that were not fully available; available in more than one database and/or those that were not in accordance with the study's objective; manuscripts such as letters to the editor; thesis; dissertations; monographs; books; manuals; and abstracts.

The collecting occurred between December 2015 and January 2016. After identifying the studies, an analytical reading of the articles was done, using a guide to describe the variables: authors; authors' education; maximum qualification of the authors; index $\mathrm{H}$; authors' institution; journal; year of publication; journal's impact factor; research's place; research's development; research's objective; the most relevant results; and key words.

The data were registered and organized in a table with the help of the software Microsoft Excel@. From the established variables, the simple descriptive method was used.

For the graphic representation of the conceptual maps of the keywords, the software CMap Tools, version 5.03, developed and free distributed by the Institute for Human Machine Cognition da University of West Florida. [7]

The objectives of the studies and the most relevant results were categorized according to the Content Analysis Technique, Categorical Theme [8], in which there are some stages, namely: pre-analysis; exploring the material or codification; treatment of the results, inference and interpretation.

\section{Results}

This study's objective was the bibliometric indicators of production and citation, with data from the most productive researchers about the referred theme, in international level, available in the databases.

A total of 127 scientific articles were analyzed: 49 articles were found in the Virtual Library in Health (BVS); 54 articles, in PubMed; and 24 articles, in Capes Journal Portal (Portal Capes). After excluding those that were not in accordance with the chosen
Table 1. Distribution of the number of authors responsable for the articles by the number of articles.

\begin{tabular}{|c|c|c|c|}
\hline \multirow{2}{*}{\multicolumn{2}{|c|}{ Number of Authors }} & \multicolumn{2}{|c|}{ Number of Articles } \\
\hline & & N & $\%$ \\
\hline \multicolumn{2}{|l|}{90} & 1 & 65.4 \\
\hline \multicolumn{2}{|l|}{10} & 3 & 15 \\
\hline \multicolumn{2}{|l|}{4} & 4 & 11.6 \\
\hline \multicolumn{2}{|l|}{2} & 10 & 4.4 \\
\hline \multicolumn{2}{|l|}{1} & 5 & 3.6 \\
\hline \multirow[t]{2}{*}{ Total } & 137 & 43 & 100 \\
\hline & \multicolumn{3}{|c|}{$\begin{array}{r}\text { Source: Authors of the research, } 2015 . \\
\text { N: frequency. \%: percentage }\end{array}$} \\
\hline
\end{tabular}

criteria, the total reduced to 42 articles.

Table 1 shows the results of the number of authors responsible for the articles according to the cooperation in the articles.

There is a decentralization of the authors concerning the publication of the studies about Social Representations and Aging. Before the findings, $65.4 \%$ (90) authors have published only one article on the topic investigated; followed by 10 authors who have produced, each, 1.5\% (2) articles; 2 authors who produced 2.2\% (3), each; 4 authors with $2.9 \%$ (4) each. Only 1 author has published 5 articles on the topic.

Concerning the index $\mathrm{H}$ of the authors, the frequencies fluctuated, with an average of three, and standard deviation of 2.63. The index $\mathrm{H}$ maximus was equal to nine, between the authors, which means that the author has nine articles with, at least, nine citations.

Table 2 shows the results of the variables referring to the authors' education and qualification.

Regarding the author's college degree, 60 (43.8\%) articles were developed by psychologists; 38 (27.7\%), by nurses; 12 (8.8\%), by physicians; 11 (8\%), by physiotherapists; two (1.5\%), by physical educators; and 11 (8\%), by other professions. However, the college degree of three (2.2\%) authors was not found. 
Table 2. Distribution of the variables referring to the authors responsible for the articles.

\begin{tabular}{|l|c|c|}
\hline \multicolumn{1}{|c|}{ Authors } & N & $\%$ \\
\hline Authors' College Degree & & \\
\hline Psychology & 60 & 43.8 \\
\hline Nursing & 38 & 27.7 \\
\hline Medicine & 12 & 8.8 \\
\hline Physiotherapy & 11 & 8.0 \\
\hline Others & 11 & 8.0 \\
\hline Not found & 3 & 2.2 \\
\hline Physical Education & 2 & 1.5 \\
\hline Authors' Qualification & & \\
\hline PhD & 90 & 65.7 \\
\hline MSc & 28 & 20.4 \\
\hline Graduation & 8 & 5.8 \\
\hline Not found & 8 & 5.8 \\
\hline Expertise & 3 & 2.2 \\
\hline Total & 137 & 100 \\
\hline Source: Auth & & \\
\hline
\end{tabular}

Source: Authors of the research, 2015. N: frequency. \%: percentage

One highlights the fact that the theme of interest has aroused interest of professionals from different areas, such as Psychology, Nursing, Physiotherapy, Physical Education, among others. Concerning the qualification, 90 (65.7\%) authors have $\mathrm{PhD}$ (65.7\%), and 28 (20.4\%), MSc.

In respect of the distribution of the institutions, 24 were Brazilian; 14 were from other countries; only one institution was not found. Regarding the number of authors, 28 (20.4\%) were from the Federal University of Paraíba, a reflection of the productivity of publications about the theme in Northern Brazil.

There was a large presence of international institutions, as the Università degli Studi Padova, in Italy, where 12 (9.1\%) authors are part of. This demonstrates the importance of the theme, in Brazil and other countries, a result of the population's aging and increase of the number of elderly people.

Table 3 shows the distribution and the frequency of the journals, their impact factors, the research's place by country and area, and the development of the study of the articles.
Table 3. Distribution of the journals and their impact factors.

\begin{tabular}{|l|c|c|c|}
\hline \multicolumn{1}{|c|}{ Journals } & N & $\%$ & $\begin{array}{c}\text { Impact } \\
\text { Factor }\end{array}$ \\
\hline Psychology \& Society & 3 & 7.1 & 0.0144 \\
\hline $\begin{array}{l}\text { Braz. Journal of Geriatrics } \\
\text { Gerontology }\end{array}$ & 3 & 7.1 & 0.2288 \\
\hline Health and Society & 3 & 7.1 & 0.3227 \\
\hline Science and Public Health & 2 & 4.8 & 0.7222 \\
\hline Psychology: Science and Profession & 2 & 4.8 & 0.2081 \\
\hline Research's Report: Basic Care Online & 2 & 4.8 & 0.2120 \\
\hline Nursing Journal UERJ & 2 & 4.8 & 0.36 \\
\hline Kairós Journal of Gerontology & 2 & 4.8 & $*$ \\
\hline Themes in Psychology & 2 & 4.8 & 0.0315 \\
\hline Others & 21 & 50.4 & \\
\hline Research's Pace
\end{tabular}

\begin{tabular}{|l|c|c|}
\hline Research's Place & 16 & 38.1 \\
\hline Brazil - Northeast & 7 & 16.7 \\
\hline Brazil - Southeast & 5 & 11.9 \\
\hline Brazil - South & 5 & 11.9 \\
\hline Do not apply** & 1 & 2.4 \\
\hline German & 1 & 2.4 \\
\hline German, Italy and Brazil & 1 & 2.4 \\
\hline Brazil - Midwest & 1 & 2.4 \\
\hline Costa Rica and Brazil & 1 & 2.4 \\
\hline Italy & 1 & 2.4 \\
\hline Italy and Brazil & 1 & 2.4 \\
\hline Mexico & 1 & 2.4 \\
\hline Paris & 1 & 2.4 \\
\hline Valencia, Spain & & \\
\hline
\end{tabular}

\begin{tabular}{|l|c|c|}
\hline Research's Development & 6 & 14.3 \\
\hline Descriptive/Qualitative & 2 & 4.8 \\
\hline Descriptive/Quanti-qualitative & 1 & 2.4 \\
\hline Descriptive/Quantitative & 2 & 4.8 \\
\hline Documentary/Descriptive & 2 & 4.8 \\
\hline Exploratory/Descriptive/Qualitative & 7 & 16.7 \\
\hline Exploratory/Qualitative & 12 & 28.6 \\
\hline Exploratory/Quanti-qualitative & 1 & 2.4 \\
\hline Reflexive & 6 & 14.3 \\
\hline Literature Review & 1 & 2.4 \\
\hline Transversal/Qualitative & 2 & 4.8 \\
\hline Transversal/Quanti-qualitative & 42 & 100 \\
\hline Total & &
\end{tabular}

Source: Authors of the research, 2015. N: frequency. $\%$ : percentage. * Not found. ${ }^{* *}$ Literature review journals. 
Figure 1: Distribution of the publications by year, found in the researched databases.

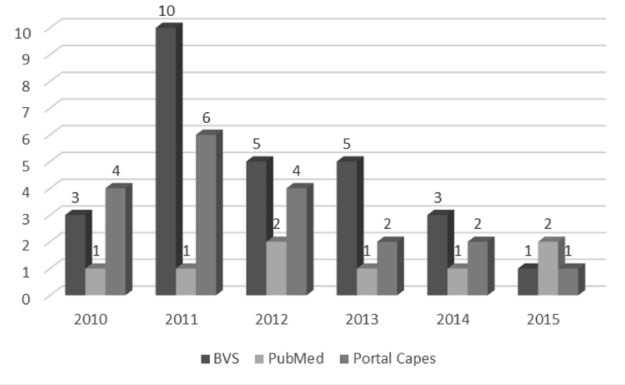

The results demonstrated that, as well as regarding the authors, there is a diversity of journals with published studies about the social representations and aging, namely: 21 (50.1\%) are journals with only one publication; three $(7.1 \%)$ have three publications; and six (4.8\%) journals with two publications.

Regarding the geographic distribution, there are 29 (69.1\%) publications about the theme in Brazil, with the following division: Northeast Region, with 16 (38.1\%); Southeast Region, with seven (16.7\%); South Region, with five (11.9\%); and only one (2.4\%) in Midwest Region. There are eight (19.2\%) international and multicentric publications, with the participation of more than one country, and only five $(11.9 \%)$ were not in accordance to the study's objective, for they are literature review, documentary or reflexive articles.

Concerning the research's development, the study's type and the used approach, the most used is the Exploratory/Quanti-qualitative, with 12 (28.6\%) publications; followed by Exploratory/Qualitative and Exploratory/Descriptive, with separated approaches, with seven (16.7\%) publications.

Figure 1 shows the distribution of the publications by year, according to the sample, that is, databases. There is an increase of the number of the publication, in 2011, in two databases, BVS and Portal Capes. There was na important increase of PubMed publications in 2012 and 2015.

After the first data collecting, the Conceptual Mapping was used, formulated with the keywords
Figure 2: Conceptual map of the keywords of scientific articles surveyed.

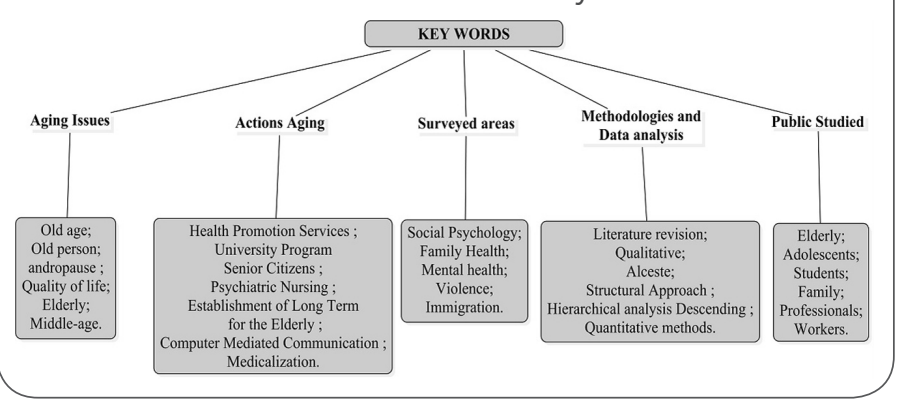

and their correlation with the theme of interest, compound by a set of informations of the publications, shown in Figure 2.

Among the keywords found in the studies, there were: aging aspects; actions focused on aging; researched areas; method and data analysis; surveyed publics.

The analysis of the objectives and the most relevant results, based on the Content Analysis Technique, Categorical Theme, created three categories: aspects about aging; care focused on the elderly; health and family professionals; and caregivers.

\section{Discussion}

The collaboration between researchers has been growing in all knowledge areas and countries, and is very important to the scientific community. The collaborative work favors the transfer of knowledge and skills, encourages the creativity and allows a better apprenticeship. The Internet access contributed to this purpose, enabling scientists from different places to work together. [9]

The index $\mathrm{H}$ is relevant for it is a standard used to demonstrate the qualitative and quantitative impact of the authors' scientific productions. [10] It is the result of the balance between the numbers of scientific publications and citations; therefore, it is defined by the number of the researcher's published articles with a number of citations equal to or higher than this number. [11]

Thereby, there was a prevalence of concerned professionals of the Psychology area in the develo- 
pment of researches about the themes social representations and aging. This may be for the fact that the Theory of Social Representations constitutes a theorical-methodological approach and originates from the Social Psychology. [12]

The theme of interest has been arousing the interest of professional from different areas, such as Psychology, Nursing, Medicine, Physiotherapy, Physical Education, etc. According to the authors [13], the researchers' college degree aggregates credibility and relevance to what's intended to be published.

Data from the Ministry of Education show that, from 2003 to 2011, the number of MSc and PhD degrees practically doubled, and the number of scholarships from CAPES and CNPq increased, contributing to the admission of professionals in the stricto sensu post-graduation courses. [14] Until 2020, the objective is to increase the number of enrollments in stricto sensu post-graduation courses, culminating in 60 thousand MSc and 25 thousand PhD degrees per year. [14]

Different results were found in other study about the Theory of Social Representations and aging in health, in which the researches were developed mostly by nurses, followed by psychologists and physiotherapists. Regarding the qualification, mostly of the researchers were clinical experts or had postgraduation degree. [15]

It is important to evidence that the Brazilian scientific and technological development focuses its activities in Southeast and South regions. However, there has been a recent increase of the activities of other regions, which may be related to the number of articles e researchers from the Northeast region. [16]

The found results are different from the conducted study about the scientific production in Brazil. In various themes regarding the aging, there was a correlation between the publications and the development of the universities; in Brazil, both publications as the institutions were from the Southeast Region. [17] Considering the publications from 2003 to 2009 , most of them, 11 (48\%) were from the Southeast Region, followed by the South Region, with 6 (26\%) publications. [15]

The most notorious university has a research group about the aging and social representations where researchers from other countries are part of, which may explain the number of publications of this institution.

According to the authors [17], the interest of researchers in studying the issues related to the aging is continuously increasing, a fact that can be explained by the increase of life expectation in Brazil and in the world.

Although there is a large number of psychologists publishing studies about the social representations and aging, the public health journals, comprising several areas of health, concentrate the studies.

Thereby, there has been an increase of the publications in the Northeast Region for the last five years. This result is consequence of the creation of more latu sensu courses in several Educational Institutions of the referred region, such as the new PhD courses of the Nursing Post-Graduation Programs of the Federal Universities of Paraíba and Rio Grande do Norte, in 2011; of the Federal University of Ceará, in 2012; and of the Federal Universities of Pernambuco and Piauí, in 2014.

Plus, there is a major Exchange of knowledge between these programs of the referred regions and other places in Brazil, such as the MSc and $\mathrm{PhD}$ programs. These programs enable a better qualification of the professional, and promote the concentration and strengthening of the educational and research's groups. [19]

One evidences, in other study about the same theme, a major frequency of studies conducted with the qualitative approach. [20] The mixed approach comprehends the complexity of the phenomena, describes particular and specific facts, with a quantitative and qualitative point of view, and may be used to comprise both data types, even emphasizing one or other. [21] 
Considering the found result, one emphasizes a study conducted in order to describe the scientific publications about social representations and aging, from 2010 to 2015, with the highest production in 2011. This demonstrates that the publications about the theme show a major concern, in the beginning of the century, with the comprehension of the aging process and its aspects. [22]

As seen, in 2011, there was an intense investment in policies and strategies promoting the raise of the quality of the Nursing Programs, focused on the education and appreciation of $\mathrm{PhD}$ researchers, and on high quality scientific production about the aging area. [23]

With the help of the conceptual map, it was possible to graphically represent an organized knowledge, whose ideas were related or intertwined. [24] Thus, five interconnections emerged, in which the themes of the studies about social representations and aging were observed.

Concerning the content analysis of the objectives and the most relevant results, three categories emerged, namely:

\section{Category 1. Aspects about aging}

The aspects about aging may directly interfere with the daily capacity of the elderly, mainly if related to any illness process. Some authors discuss this process, especially emphasizing, in their results, the negative positioning regarding the aging. [25]

In this context, other studies discuss about this process as a life stage that needs to be more appreciated, as well as a positive positioning regarding the independence on the aging process; on the other side, they expose a negative association between aging, decay and ending of life. [26]

\section{Category 2. Attention focused on the elderly}

In the perspective of the attention focused on the elderly, the studies denote that being able to live independently interferes with the elderly's quali- ty of life. [27] The higher the life expectation, the more they need attention, especially of the health services; this need is enhanced by certain studies about the theme. [27] Some studies about the social representations of aging in the perspective of the elderlies themselves show a positive positioning related to the importance of the family and caregivers when helping the elderly. [28]

\section{Category 3. Health and family professionals and caregivers}

The found studies about the health and family professionals and caregivers emphasize the knowledge of these groups about the aging process; they evidence the positive and negative aspects, as well as highlighted by other authors [29], and the importance of the health professionals in identifying the weaknesses and vulnerabilities experienced by the elderlies.

It is possible to find literature about the healthy and active aging and the development of policies to adapt the basic care services in order to properly attend the elderlies, according to their specific needs. [30]

\section{Conclusions}

In this study, it was possible to notice that the biObliometric indicators, regarding the authorship of the articles, demonstrate a decentralization of the publications, by the number of documents, with more authors from the Northeast region, an opposite result from previous studies, with more authors from the Southeast region.

In addition, the exploratory study and the mixed approach represented the majority of the research's methods, for they describe specific events, from the quantitative and qualitative point of view. One denoted an increase of the number of publications in 2011, with twice more publications when compared to other years, resembling other studies about the theme. 
The publications indicated aspects about the aging, emphasizing the social representations and positive and negative points of view related to the aging. Concerning the attention focused on the elderly, the studies denote that the dependence on other person while performing daily activities interferes with the quality of life. Among the publications about the representations, the positioning and knowledge of the health and family professionals and caregivers, one emphasizes the importance of the use of the Theory of Social Representations in identifying the weaknesses and vulnerabilities experienced by the elderlies.

This study's limitation can be solved in future researches about the health of the elderly, especially concerning the international researches, in order to understand the social representations of the elderly.

Lastly, it is believed that this study may contribute to the increase of discussions and reflections about the social representations, in order to promote and improve psychosocial policies of public health focused on the elderlies.

\section{Contribution of authors}

KLA, AKFJA, SGM, CBE and CMCPS worked in all phases of development, from conception, design, analysis and interpretation of the data, writing of the manuscript; KLA, AKFJA, SGM and CBE prepared the database; KLA performed critical review of the manuscript; AOS, MASPM, conducted orientation of the manuscript and approved the final version to be published.

\section{Conflict of interest}

The authors declare the absence of conflict of interest.

\section{References}

1. Instituto Brasileiro de Geografia e estatística. Perfil dos idosos responsáveis pelos domicílios. Censo 2010: Brasil. [base de dados na internet]. Brasil. 2011. [Acesso 1501 2016]. Disponível em: www.ibge.gov.br/home/presidencia/.../25072002pidoso.shtm

2. Gastrón L. Monchietti A. Oddone M J. Representações sociais sobre homens e mulheres na velhice. In: Tura LFR. Silva AO. Envelhecimento e Representações Sociais. Ed.1. Rio de Janeiro: Quartet: Faperj; 2012. p. 117-73.

3. Moscovici S. Representações sociais: investigações em psicologia social. Petrópolis, RJ: Vozes. 2003.

4. Jodelet D. Representações Sociais: um domínio em expansão. In: Jodelet D. As representações sociais. Rio de Janeiro: EDUERJ; 2001. p.17- 44

5. Paiva MLG, Rodrigues TP, Moreira MASP, Matos MYC, Ferreira OGL, Silva LM. Velho no Olhar de Idosos: representações sociais. R pesq Cuid Fundam Online. 2011; dez. 122-131.

6. Silveira Guedes VL. A Bibliometria e a Gestão da Informação e do Conhecimento Científico e Tecnológico: uma revisão da literatura. Ponto de Acesso. 2012; v. 6, n. 2, p. 74-109.

7. Institute for Human and Machine. Cognition-Cmap Tools [Internet]. Florida (US): University of West Florida; 2014 [acesso 12 jan 2016]. Disponível em: http://cmap.ihmc.us/.

8. Bardin L. Análise de Conteúdo. 70 ed. Lisboa; 2009.

9. Vanz SAS, Stump IRC. Colaboração científica: revisão teóricoconceitual. Perspectivas em Ciência da Informação. 2010;15(2):42-55.

10. Speller FR, Meneghel SM. Desafios e perspectivas da educação superior brasileira para a próxima década. UNESCO, CNE, MEC. Brasília; 2012.

11. Thomaz PG, Assad RS, Moreira LFP. Uso do Fator de impacto e do índice $\mathrm{H}$ para avaliar pesquisadores e publicações. Arq Bras Cardiol. 2011; 96(2):90-3.

12. Wachelke JFR. Índice de Centralidade de Representações Sociais a partir de Evocações: exemplo de aplicação no estudo da representação social sobre Psicologia. Reflexão e Críticaexão Crítica. 2009;22(1):102-10.

13. Medeiros KKAS, et al . Perfil bibliométrico da produção científica (inter)nacional da Enfermagem Gerontogeriátrica. Rev bras geriatr gerontol. 2014;17(2):425-38.

14. Ministério da Educação. Coordenação de Aperfeiçoamento de Pessoal de Nível Superior - Capes. Contribuição da pós-raduação brasileira para o desenvolvimento sustentável: Capes na Rio+20/ Brasília/Brasil. (2012).

15. Smith AAF, Costa LS, Oliveira AMF, Silva AO, Caliri MHL, Silva LM. Teoria das Representações Sociais no Âmbito do Envelhecimento: Uma Revisão Integrativa. R. pesq cuid fundam online. 2011; 242-250. 
16. Moser AC, Theis Im. Investimentos em C\&T e desigualdades socioespaciais no Brasil. Tempo Social, revista de sociologia da USP. 2014;26(2):187-207.

17. Jerez-Roig J, Guedes MBOG, Silva JMD, Lima KC. Análise da produção científica da Revista Brasileira de Geriatria e Gerontologia: uma revisão bibliométrica. Rev Bras Geriatr Gerontol. 2014; 17(3):659-671.

18. Silva NNL, Xavier MP. A terceira idade como foco das propagandas midiáticas de consumo. Psic Rev. 2012;21(2):20315.

19. Brasil. Ministério da Educação. Coordenação de Aperfeiçoamento de Pessoal de Nível Superior. Plataforma Sucupira. Levantamento de cursos de doutorado em funcionamento por região. [Internet]. Brasilia, DF; 2015. [acesso em 12 jan 2016] Disponível em: $\quad$ https://sucupira.capes.gov.br/sucupira/public/consultas/ coleta/programa/listaPrograma.jsf

20. Aguiar ESS, Gomes IP, Fernandes MGM, Silva AO. Representações Sociais do Cuidar de Idosos para Cuidadores: Revisão Integrativa. Rev enferm UERJ. Rio de Janeiro, 2011; 19(3):485-90.

21. Prates JC. O método marxiano de investigação e o enfoque misto na pesquisa social: uma relação necessária. Textos \& Contextos. 2012; v. 11, n. 1, p. 116-128

22. Ferreira OGL, Maciel SC, Silva AO, Sá RCN, Moreira MASP. Significados atribuídos ao envelhecimento: idoso, velho e idoso ativo. Psico-USF. 2010; v. 15, n. 3, p. 357-364.

23. Scochi CGS. et al. Pós-graduação Stricto sensu em Enfermagem no Brasil: avanços e perspectivas. Rev bras enferm. Brasília. [Imternet]. 2013 [acesso em 20 jan 2016]; v.66, n. spe, p.8089. Disponível em: http://www.scielo.br/scielo.php?script=sci arttext\&pid=S0034-71672013000700011\&lng=en\&nrm=iso

24. Azevedo Júnior W. Mapas conceituais: instrumentos para compreensão de textos. Biblioteca Virtual do NEAD/UFJF. [Internet] 2009. [acesso em 19 jan 2016]. Disponível em: http://www.cead.ufjf.br/wp-content/uploads/2009/02/media biblioteca mapas conceituais.pdf

25. Ferreira OGL, Maciel SC, Silva AO, Santos WS, Moreira MASP O envelhecimento ativo sob o olhar de idosos funcionalmente independentes. Rev Esc Enferm USP. 2010; 44(4):1065-9.

26. Pereira RF, Freitas MC, Ferreira MA. Velhice para os adolescentes: abordagem das representações sociais. Rev bras enferm. Brasília. $2014 ; 67(4)$
27. Costa e Silva SP, Menandro MCS. As representações sociais da saúde e de seus cuidados para homens e mulheres idosos. Saude soc. São Paulo. 2014; 23(2).

28. Brito TDQ, Oliveira AR, Eulálio $M C$. Deficiência física e envelhecimento: estudo das representações sociais de idosos sob reabilitação fisioterápica. Avances en Psicología Latinoamericana. Bogotá. 2015; Vol. 33(1): 121-133.

29. Mendes CKTT, Alves MSCF, Silva AO, Paredes MAS, Rodrigues TP. Representações sociais de trabalhadores da atenção básica de saúde sobre envelhecimento. Rev Gaúcha Enferm. 2012;33(3):148-155

30. Ministério da Saúde. Secretaria de Atenção à Saúde. Departamento de Atenção Básica. Envelhecimento e saúde da pessoa idosa Brasília/Brasil. (2006).
Publish in International Archives of Medicine

International Archives of Medicine is an open access journal publishing articles encompassing all aspects of medical science and clinical practice. IAM is considered a megajournal with independent sections on all areas of medicine. IAM is a really international journal with authors and board members from all around the world. The journal is widely indexed and classified Q1 in category Medicine. 